\title{
The Influence of Education and Training on Professional Economics Education Teachers
}

\author{
Amiruddin 1 , Zakaria ${ }^{2}$, Venny Arvianita ${ }^{3}$ \\ Economic Education Study Program FKIP, Syiah Kuala University \\ e-mail:_amiruddin.eko@gmail.com
}

\begin{abstract}
The purpose of this research aimed to know the number of training which is followed by teachers during their working period as the teacher of economics. Furthermore, this study addressed to know the professional level of teacher, and to understand the influence of education and training to the professional teacher of economic education, research towards teachers of state high school in Banda Aceh. The approach used in this research is quantitative approach with descriptive research type while the sample was taken by using random sampling technique is only 28 economic teachers from 10 high schools in Banda Aceh. Data analysis technique is accomplished by using simple correlation analysis formula. There may be positive and significant relationship between education and training with professional economic education teachers in 10 state senior high schools in Banda Aceh,
\end{abstract}

Keywords: Training, professional teachers, education

\section{INTRODUCTION}

In accordance with the Republic of Indonesia constitution No.14 of 2005 concerning article 8 about teachers and lecturers namely teachers must have academic qualifications, competencies, educator certificates, physically and mentally healthy, and have the ability to embody national education goals. Professional teachers rely heavily on the level of education that they took as well as their expertise, taking into consideration the fact that teacher position is one of the professional positions. Professional refers to a job or position that requires professional expertise, responsibility and loyalty. A profession theoretically cannot be conducted by just anyone who is not trained or prepared for it (Mihaela, 2014). In addition to the demands for education level requirements and in order to make teachers become more professional, each teacher must attend the training or upgrading program (Neghavati, 2016). For instance, training in learning models, making teaching props, syllabus development, and making materials. Through these trainings, new information and teaching methods can be quickly absorbed by the teacher, hence those are able to increase the ability and motivation of the teachers to carry out their work (Neghavati, 2016; Paredes-Chi \& Castillo-Burguete, 2018).

A teacher is obliged to improve his professionalism. Likewise, the economic teachers of state high schools in Banda Aceh will keep continue to improve their quality. Based on preliminary observations in state high schools in Banda Aceh, it shown that professional economic teachers were still not optimal. Teachers of Economic subject only teach memorization (verbally), learning is directed at the skill of memorizing economic science 
concepts from economics theories that economists stated as written in textbooks. Students are only taught to memorize subject matter from other textbooks and information sources.

Materials source from textbooks are concepts or information's that are not applicable in the students daily lives, therefore, students may feel that the concepts or information in the textbooks are not what can be accomplished obviously in their daily lives, only the knowledge that needs to be understood in order to be able to answer block exam questions, midterm and final exams, as result they may obtain high scores and can pass the exam. The objective is to know the amount of training that followed by the teachers during working as a teacher of economic in Banda Aceh state high school.

\section{METHOD}

The approach used in this research is a quantitative approach, while the type is descriptive. Subsequently there were population of 53 economic teachers from 16 state high school in Banda Aceh, but the samples that taken using the sampling technique were only 28 economic teachers from 10 state high school in Banda Aceh. The collection technique in this research is literature and field review through a questionnaire as well as the data analysis technique used is simple correlation analysis techniques.

\section{RESULTS \& DISCUSSION Results}

Based on the processed data from the questionnaire that given to economic teachers, there are numbers of training courses were attended by the teachers during their tenure as economic teachers in Banda Aceh City state high school and the following frequencies as well as percentages can be determined as the following.

Table 1. Frequency Distribution of Education and Training

\begin{tabular}{lll}
\hline $\begin{array}{l}\text { Level of Education and } \\
\text { Training }\end{array}$ & Frequency & Percentage (\%) \\
\hline District & 2 & $7.14 \%$ \\
Regency & 25 & $89.28 \%$ \\
Province & 28 & $100 \%$ \\
National & 9 & $32.14 \%$ \\
International & 0 & $0 \%$ \\
\hline
\end{tabular}

Source: Authors (2018)

From Table 1, it can seen the number and percentage of education and training level were attended by economic education teachers in Banda Aceh state high school. Based on the level of education and training, the respondents were dominant at the provincial level, which were 28 people or 100 percent. While at the regency level were 25 people or 89.28 percent at the district level were 2 people or 7.14 percents and at the national level were 9 people or 32.14 percents however at the international level there are 
no teachers who will join the program.

Based on the collecting and processing data has been conducted, the results of the research show that there is a positive and significant relationship between education and training with teacher professionals in the 10 of state senior high schools in Banda Aceh which is shown by the correlation of $r=0.45$, can be seen in the product moment correlation index numbers roughly or simply located at the number 0.40-0.599 which means the correlation between variable $\mathrm{X}$ and $\mathrm{Y}$ is a moderate correlation. That correlation is due to the relatively similar knowledge and abilities of economic education teachers, then the teaching experience is also relatively the same, the respondents are dominant with a working period of 11-20 years, and approximately 96 percent of economic teachers are already certified. Therefore, the correlation between variable $\mathrm{X}$ and $\mathrm{Y}$ is not very visible or moderate.

\section{Discussion}

This findings is supported by the theory that was stated by Mulyawan (2012) which mentioned that professional teachers have two characteristics, they are either at a high level of ability or in high commitment. Therefore, teacher's professional development must be directed at these two things. Certification and competency testing need to be carried out periodically in order to improve the professional abilities of teachers first, furthermore their performance still continues increase and meet professional requirements.

With this correlation results, it depicts that education and training have contributed as much 20.25 percent towards professional teachers in 10 state high schools in Banda Aceh and the remaining 79.75 percent is influenced by other factors such as teaching experience, and the number of books owned (related to subjects) or the facilities provided are sufficient. After participating in training, teachers usually join in a study group coordinated by the principal. Training materials have been arranged in learning packages as well as each package has been prepared. All lessons are prepared by a team consisting of deputy head of the curriculum (vice head curriculum), subject matter teachers (experienced teachers), instructional technology experts (learning), and MGMP supervisors (subject teacher consultation).

The better of training that has been followed, the better of performance capability is as expected. This is supported by (Amponsah et al., 2018; Neghavati, 2016; Paredes-Chi and Castillo-Burguete, 2018) teachers training is an attempt to transfer skills and knowledge towards the participants in way hence the teachers are able to receive and carry out the training while working. The knowledge and skills developed must be specific and training must be directed at identified behavioral changes. Training must also learn specific skills or techniques that can be demonstrated and observed at the place of assignment. 


\section{CONCLUSION}

The results showed that there ware a positive and significant relationship between education and training on professional economic education teachers in 10 state high schools in Banda Aceh. Therefore, education and training program could contribute to the professional ability of teachers. Furthermore, with this findings, education and training have contributed as much 20.25 percent towards professional teachers in 10 state high schools in Banda Aceh and the remaining 79.75 percent is influenced by other factors such as teaching experience, and the number of books owned (related to subjects) or the facilities provided are sufficient.

\section{REFERENCES}

Amponsah, S., Kwesi, A.B., Ernest, A., 2018. Lin's creative pedagogy framework as a strategy for fostering creative learning in Ghanaian schools. Thinking Skills and Creativity 31, 11-18. https://doi.org/10.1016/j.tsc.2018.09.002

Mihaela, P.L. 2014. Psychological Variables to Professional Satisfaction for Teachers. Procedia - Social and Behavioral Sciences, The International Conference psychology and the realities of the contemporary world 4th edition - psiworld 2013 127, 807-811. https://doi.org/10.1016/j.sbspro.2014.03.359

Mulyawan, B. 2012. Journal of Influence of Experience in Training on Enhancing Teacher Professional Competence. Undiksha Singaraja Penjaskesrek Department (Indonesia Origin)

Neghavati, A., 2016. Core Skills Training in a Teacher Training Programme. Procedia - Social and Behavioral Sciences, International Conference on Teaching and Learning English as an Additional Language, GlobELT 2016, 14-17 April 2016, Antalya, Turkey 232, 617-622. https://doi.org/10.1016/j.sbspro.2016.10.085

Novitasari, A. 2012. Journal of the Effect of Principal Leadership, Work Environment, Education and Training on Teacher Performance. Semarang: Department of Economic Education, Faculty of Economics, Semarang State University (Indonesia origin)

Paredes-Chi, A.A., Castillo-Burguete, M.T., 2018. Is Participatory Action Research an innovative pedagogical alternative for training teachers as researchers? The training plan and evaluation for normal schools. Evaluation and Program Planning 68, 176-184. https://doi.org/10.1016/j.evalprogplan.2018.03.007

Undang-Undang Republik Indonesia Nomor 14 Tahun 2005 tentang Guru dan Dosen.

Wahyuningtyas, R. 2010. Jurnal Pengaruh Tingkat Pendidikan, Pelatihan, dan Pengalaman Mengajar terhadap Profesionalisme Guru ekonomi di SMA se-Kota Probolinggo. Malang: Pendidikan Ekonomi dan Koperasi FE Universitas Negeri. 